
\title{
MASTER
}

\section{DETERMINATION OF SUBMICROGRAM QUANTITIES OF MERCURY IN WATER AND LITHIUM HYDROXIDE SOLUTIONS}

M. S. Dill

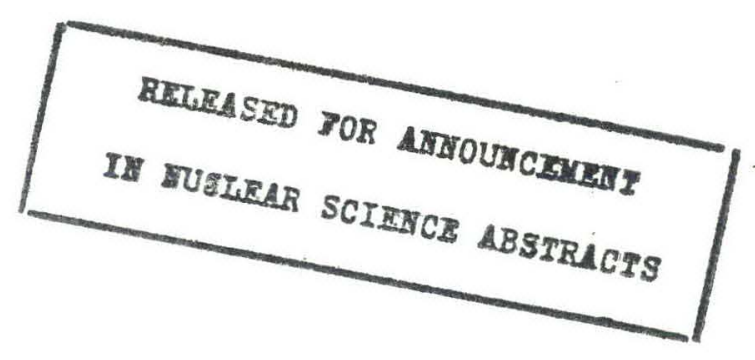

\section{UNION CARBIDE CORPORATION}

\section{NUCLEAR DIVISION}

OAK RIDGE Y-12 PLANT

operated for the ATOMIC ENERGY COMMISSION under U. S. GOVERNMENT Contract W-7405 eng 26 


\section{DISCLAIMER}

This report was prepared as an account of work sponsored by an agency of the United States Government. Neither the United States Government nor any agency Thereof, nor any of their employees, makes any warranty, express or implied, or assumes any legal liability or responsibility for the accuracy, completeness, or usefulness of any information, apparatus, product, or process disclosed, or represents that its use would not infringe privately owned rights. Reference herein to any specific commercial product, process, or service by trade name, trademark, manufacturer, or otherwise does not necessarily constitute or imply its endorsement, recommendation, or favoring by the United States Government or any agency thereof. The views and opinions of authors expressed herein do not necessarily state or reflect those of the United States Government or any agency thereof. 


\section{DISCLAIMER}

Portions of this document may be illegible in electronic image products. Images are produced from the best available original document. 
Printed in the United States of America. Available from Clearinghouse for Federal

Scientific and Technical Information, National Bureau of Standards,

U.S. Department of Commerce, Springfield, Virginia 2215

Price: Printed Copy $\$ 3.00$; Microfiche $\$ 0.65$

\section{LEGAL NOTICE}

This report was prepared as an account of Government sponsored work. Neither the United States, nor the Commission, nor any person acting on behalf of the Commission:

A. Makes any warranty or representation, expressed or implied, with respect to the accuracy, completeness, or usefulness of the information contained in this report, or that the use of any information, apparatus, method, or process disclosed in this report may not infringe privately owned rights; or

B. Assumes any liabilities with respect to the use of, or for damages resulting from the use of any information, apparatus, method, or process disclosed in this report.

As used in the above, "person acting on behalf of the Commission" includes any employee or contractor of the Commission, or employee of such contractor, to the extent that such employee or contractor of the Commission, or employee of such contractor prepares, disseminates, or provides access to, any information pursuant to his employment or contract with the Commission, or his employment with such contractor. 
UNION CARBIDE CORPORATION Nuclear Division

\section{$Y-12$ PLANT}

Contract W-7405-eng-26

With the US Atomic Energy Commission
IX:C:

Bret 
Distribution:

\begin{tabular}{|c|c|c|c|}
\hline Ackerson, R. D. & (AFSC) & Huber, A.P. & (ORGDP) \\
\hline Andrew, R. E. & & Keller, C. A. & $(A E C-O R O)(4)$ \\
\hline Bailey, E. W. & & McLendon, J. D. & \\
\hline Ballenger, H.F. & (2) & Meeks, E. J. & (AFSC) \\
\hline Barton, T. H. & & Mitchel, G.W. & \\
\hline Bell, B. B. & & Schwenn, M. F. & \\
\hline Bernander, N.K. & & Stewart, J. H. & \\
\hline Briscoe, O.W. & & Strasser, G. A. & \\
\hline Burkhart, L. E. & & Wesley, R. L. & \\
\hline Center, C. E. & (ORGDP) & Whitson, W. K. & \\
\hline Dill, M.S. & (15) & Winkel, R.A. & (Paducah) \\
\hline Farrar, R. B. & (ORGDP) & Wood, D. C. & \\
\hline Harwell, W. L. & (ORGDP) (5) & Y-12 Central Files & (25) \\
\hline Hemphill, L. F. & & Y-12 Central Files & $(Y-12 R C)$ \\
\hline
\end{tabular}

In addition, this report is distributed in accordance with the category Chemistry as given in the "USAEC Standard Distribution Lists for Unclassified Scientific and Technical Reports", TID-4500. 


\section{ABSTRACT}

A method has been developed for determining submicrogram quantities of mercury in water and lithium hydroxide. The detection limit is $2 \times 10^{-4}$ micrograms permilliliter. The mercury is reduced to metal and then expelled from a solution as vapor. The vapor is measured using an atomic absorption spectrophotometer. 


\section{CONTENTS}

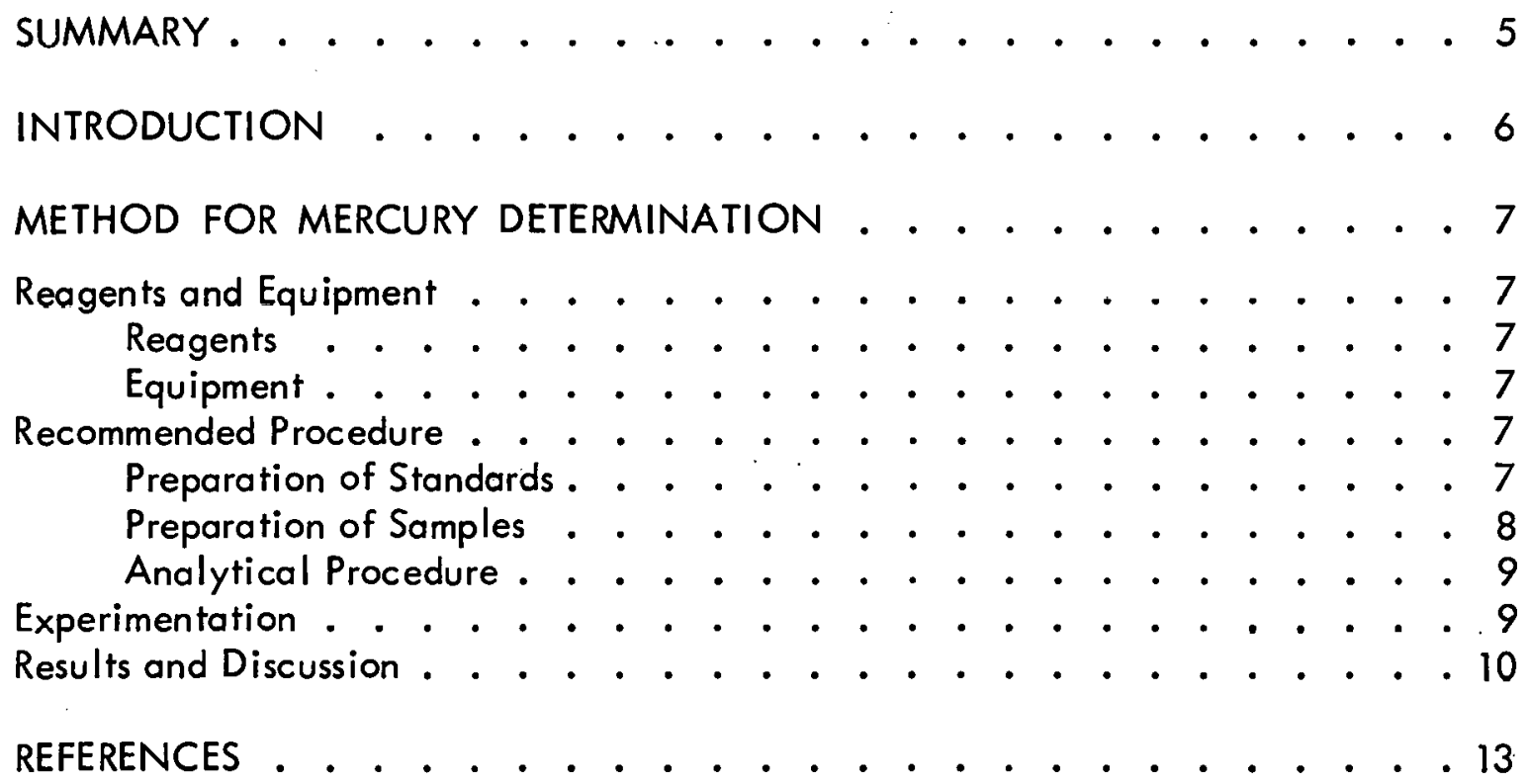


An atomic absorption spectrophotometric method for determining submicrogram amounts of mercury has a detection limit of $2 \times 10^{-4} \mathrm{kgs} / \mathrm{ml}$ and a precision of \pm 10 percent at the $2 \times 10^{-3} \mathrm{\mu gs} / \mathrm{ml}$ level, when based upon a 50 -milliliter sample. The total mercury content of an aliquant must be less than one microgram for the determination by this method.

The method consists of: (1) converting the mercury ions to the metal, (2) expelling the metallic mercury as the vapor, and (3) measuring the vapor in an absorption cell. Time required for an analysis is approximately five minutes per sample.

The only interferences found were vapors which absorb at $2537 \mathrm{~A}$ and metallic ions which are reduced to the metal and form an alloy with the metallic mercury. 


\section{INTRODUCTION}

The Biology Division of the Oak Ridge National Laboratory asked that some water samples be analyzed to see if the mercury concentration exceeded $1 \times 10^{-2} \mathrm{kgs} / \mathrm{ml}$. A new method had to be found because the lower limit of the mercurometer was $5 x$ $10^{-2} \mathrm{kgs} / \mathrm{ml}$; the colorimetric procedure $(1)$ was too time consuming.

Several papers on mercury analysis by atomic absorption have been published, but most of these methods require a solvent extraction of the mercury ion into an organic phase to concentrate the mercury before atmoizing into the flame. These methods are often inadequate because: (1) mercury in the water is usually in the metallic form, and (2) extraction does not concentrate the mercury sufficiently, if one is interested in submicrogram quantities.

Russian workers published an article on the analysis of mercury in the gas phase using a tomic absorption (3). This principle, adapted to the Laboratory's samples and equipment, was utilized in developing the present method of determining submicrogram quantities of mercury in water and in lithium hydroxide solutions. 


\section{METHOD FOR MERCURY DETERMINATION}

\section{REAGENTS AND EQUIPMENT}

Reagents

The following reagents are required:

Stannous Chloride Solution, 20\% - Dissolve 20 grams of CP tin (II) chloride dihydrate in 100 milliliters of 6 normal hydrochloric acid.

Mercury Solution, $100 \mathrm{kgs} / \mathrm{ml}$ - Dissolve 108 milligrams of mercury(II) oxide in 50 milliliters of 5 normal nitric acid. Dilute with water to the mark in a 1000-milliliter volumetric flask.

Mercury Solution, $0.1 \mathrm{kgs} / \mathrm{ml}$ - Pipette one milliliter of the standard mercury(II) oxide solution $(100 \mathrm{kgs} / \mathrm{ml})$ into a 1000 -milliliter flask and dilute with 0.25 normal nitric acid to the mark.

\section{Equipment}

The following major items of equipment are needed: an atomic absorption spectrophotometer ${ }^{(a)}$ equipped with a recorder readout, and an absorption cell and reaction train (see Figure 1).

\section{RECOMMENDED PROCEDURE}

\section{Preparation of Standards}

The standard solutions should be prepared as follows:

1. Pipette the mercury standard solution $(0.1 \mathrm{kgs} / \mathrm{ml})$ into the reaction flasks in known amounts to give a series of five standards to cover the expected range of samples. (The highest standard that can be used is $1.0 \mathrm{~kg} \mathrm{Hg}$ total.)

2. Dilute the standard solution in the reaction flask to a 50 -milliliter volume.

(a) Model 303, Perkin-Elmer Corporation. 


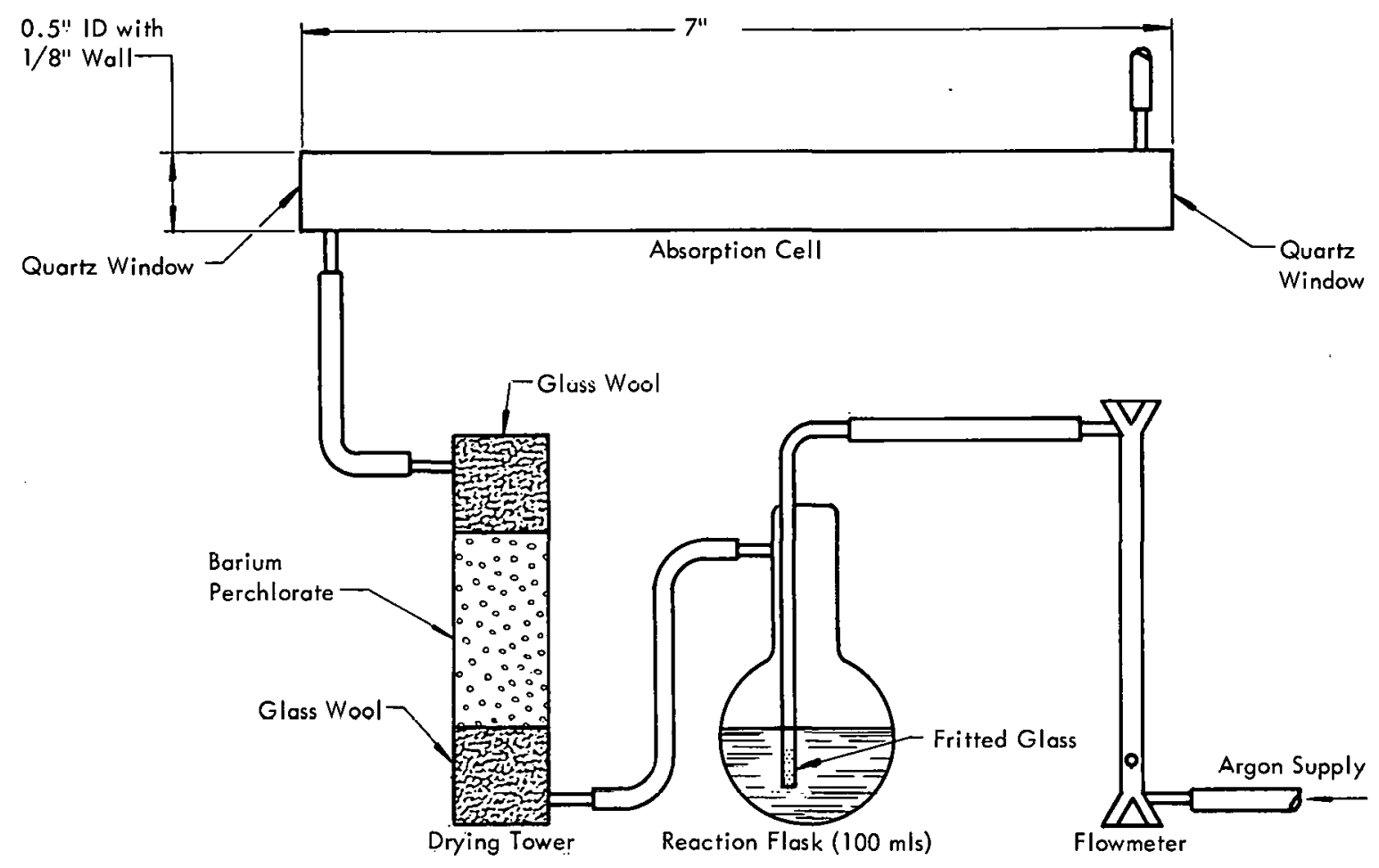

Figure 1. MERCURY ABSORPTION CELL AND REACTION TRAIN.

3. Add 0.5 milliliter of tin(II) chloride solution to each reaction flask. Stopper the flask and invert five times to provide thorough mixing.

4. React the standard within ten minutes after the addition of the tin chloride. Preparation of Samples

Samples should be prepared as follows:

1. Pipette into the reaction flask a portion of sample which gives a total mercury value corresponding to the standard curve.

2. If the sample is basic, add nitric acid until the $\mathrm{pH}$ is less than 7 .

3. Dilute the sample in the reaction flask to a 50-milliliter volume.

4. Add 0.5 milliliter of tin(II) chloride solution to the reaction flask. Stopper the flask and invert five times to provide thorough mixing.

5. React the samples within ten minutes after the addition of the tin chloride. 


\section{Analytical Procedure}

The analysis for mercury should be conducted according to the following procedure:

1. Remove the burner from the instrument and install the mercury absorption cell.

2. Align the absorption cell to obtain maximum intensity of the mercury source lamp through the cell.

3. The instrument operating conditions are:

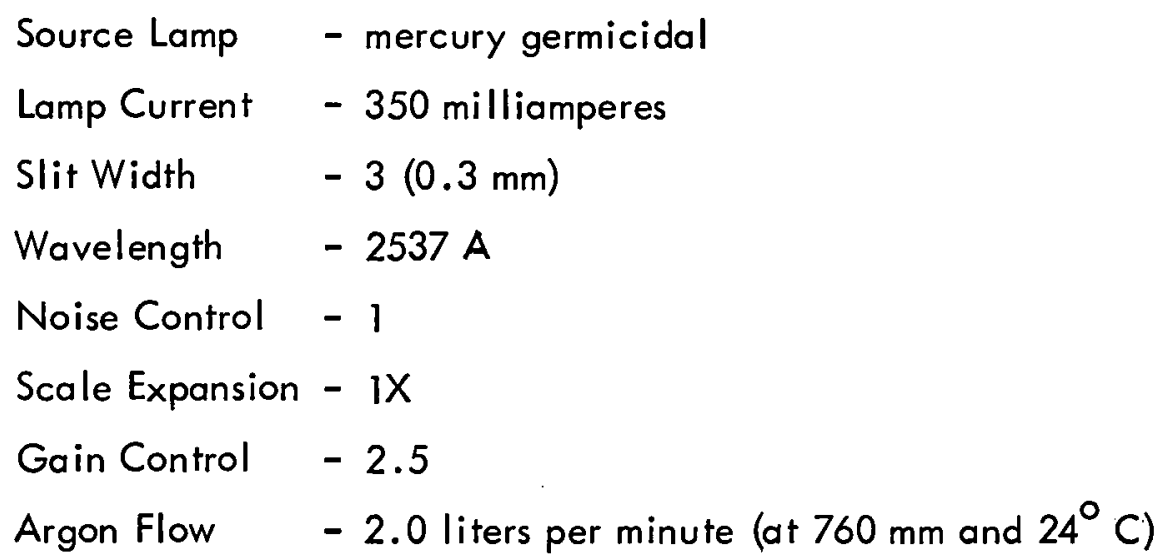

4. Adjust the recorder to zeroabsorbance, then insert the gas dispersion adapter into the reaction flask and allow it to remain until the recorder returns to zero absorbance.

5. Compare the sample absorbance data to the absorbance data of the standards to obtain the total micrograms of mercury in the reaction flask.

6. Colculate the results by the following equation:

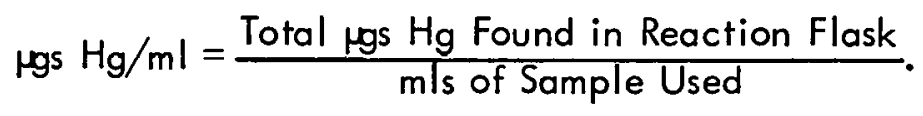

\section{EXPERIMENTATION}

Synthetic samples were prepared by adding mercury(II) nitrate to water and lithium hydroxide solutions. The lithium hydroxide concentration was approximately 2.5 $\mathrm{mgs} \mathrm{Li} / \mathrm{ml}$. Typical results of these experiments are summarized in Table 1 . 
Table 1

ANALYSIS FOR MERCURY IN WATER AND LITHIUM HYDROXIDE SOLUTIONS

\begin{tabular}{|c|c|c|c|c|}
\hline $\begin{array}{l}\text { Sample } \\
\text { Number }\end{array}$ & $\begin{array}{l}\text { Total } \\
\text { Mereury } \\
\text { Added } \\
(\mu g)\end{array}$ & $\begin{array}{l}\text { Total } \\
\text { Mercury } \\
\text { Found } \\
(\mu g)\end{array}$ & $\begin{array}{c}\text { Actual Mercury } \\
\text { Value } \\
\text { (in } \mu g s \mathrm{Hg} / \mathrm{ml} \text { ) }\end{array}$ & $\begin{array}{c}\text { Mercury Value } \\
\text { Obtained } \\
\text { (in } \mathrm{gg}_{\mathrm{Hg}} \mathrm{Hgl} \text { ) }\end{array}$ \\
\hline \multicolumn{5}{|c|}{ Water } \\
\hline 1 & 0.100 & 0.100 & 0.002 & 0.00200 \\
\hline 2 & 0.100 & 0.095 & 0.002 & 0.00190 \\
\hline 3 & 0.100 & 0.098 & 0.002 & 0.00196 \\
\hline 4 & 0.100 & 0.105 & 0.002 & 0.00210 \\
\hline 5 & 0.100 & 0.095 & 0.002 & 0.00190 \\
\hline 6 & 0.100 & 0.100 & 0.002 & 0.00200 \\
\hline 7 & 0.100 & 0.106 & 0.002 & 0.00212 \\
\hline 8 & 0.100 & 0.098 & 0.002 & 0.00196 \\
\hline 9 & 0.100 & 0.103 & 0.002 & 0.00206 \\
\hline 10 & 0.100 & 0.101 & 0.002 & 0.00202 \\
\hline \multicolumn{5}{|c|}{ Lithium Hydroxide } \\
\hline 1 & 0.4750 & 0.470 & 0.0475 & 0.0470 \\
\hline 2 & 0.4750 & 0.475 & 0.0475 & 0.0475 \\
\hline 3 & 0.4750 & 0.475 & 0.0475 & 0.0475 \\
\hline 4 & 0.4750 & 0.490 & 0.0475 & 0.0490 \\
\hline 5 & 0.4750 & 0.480 & 0.0475 & 0.0480 \\
\hline 6 & 0.1750 & 0.475 & 0.0475 & 0.0475 \\
\hline 7 & 0.4750 & 0.465 & 0.0475 & 0.0465 \\
\hline
\end{tabular}

\section{RESULTS AND DISCUSSION}

Atomic absorption analysis of mercury in the vapor phase in an absorption cell has the following advantages over the burner method: (1) all of the mercury is in the zero energy state; (2) there is no interference from burning conditions; (3) there is no flame "noise"; and (4) very low detection limits can be reached. The disadvantages are that: (1) samples may contain organic vapors which absorb at $2537 \mathrm{~A}$ giving false readings, and (2) metallic ions may be present which would be reduced to the metal with tin(II) chloride that would then be alloyed with the mercury to prevent it from being expelled from the solution. Metals known to interfere are gold, platinum, selenium, and tellurium. (4)

The presence of organic vapors that absorb in the 2537 A region can be detected by the response of the chart recorder, as shown in Figure 2. The failure of the recorder pen to return to zero absorbance indicates that an absorbing vapor is being expelled at a constant rate. Several organics that absorb at $2537 \mathrm{~A}$ were tested but none were 
found that expelled as quickly as possible. All reacted similarly to acetone, shown in Figure 2.

The samples can be checked for the interference of metallic ions by spiking with mercury and checking the recovery. Failure to recover the spike indicates interfering metallic ions.

The glass frit in the reaction tube is necessary to produce a fast and constant rate of expelling the mercury vapor. An open-end tube was found unsatisfactory for use .

It is necessary to dilute the samples and standards to the same volume. The gas flow rate must be held constant since this determines the rate at which the mercury is expelled and the number of atoms in the absorption path at any given time.

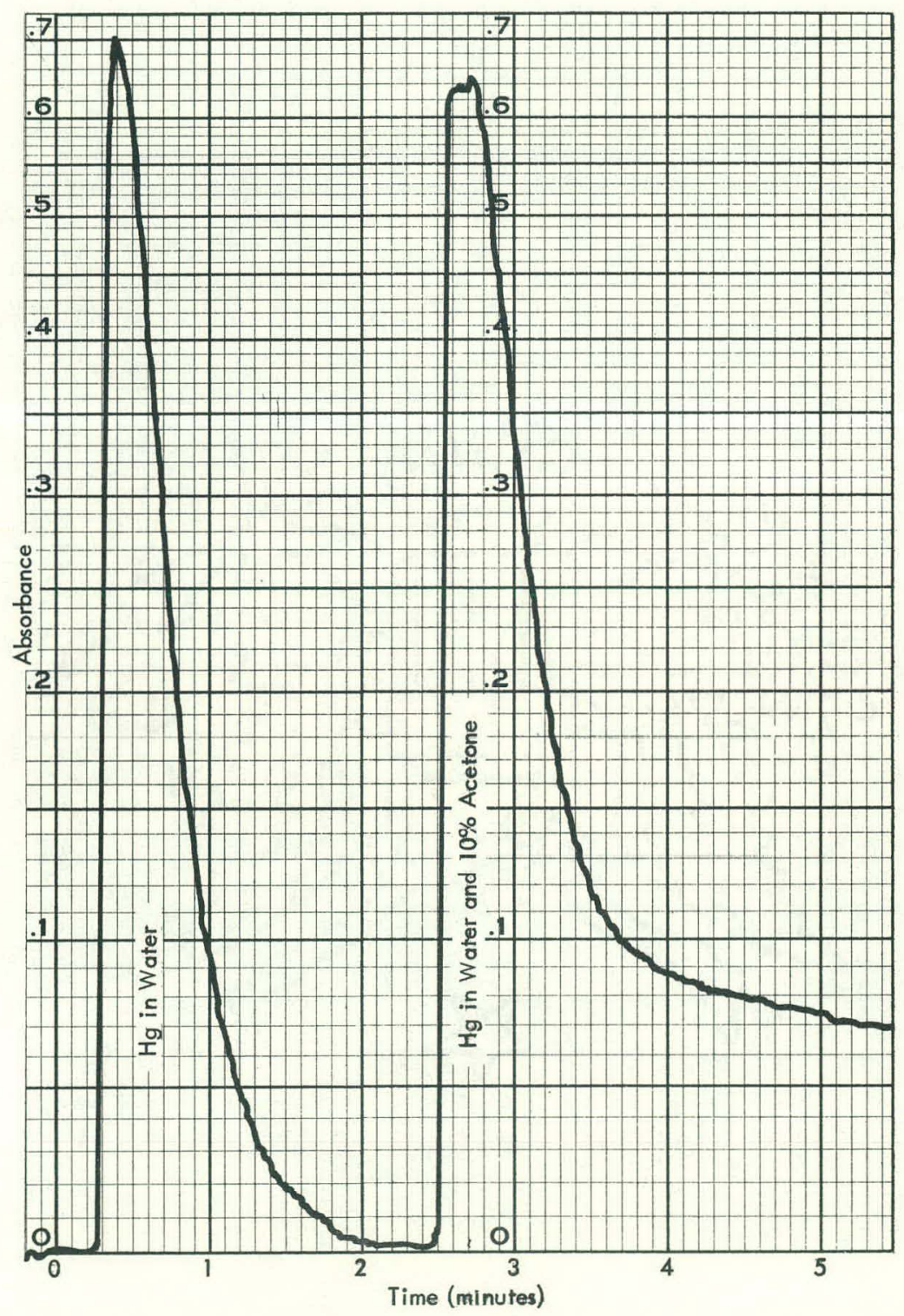

Figure 2. EFFECT OF ORGANIC VAPORS ON ABSORBANCE. 
The concentration of sulfuric, nitric, and perchloric acids and mixtures of these acids did not affect the results below five normal. Above this concentration, nitric acid will decompose and release fumes which will absorb, giving false readings.

To obtain total absorbance of a sample, an integrating recorder was tried and found to be unnecessary because of the fast and constant rate at which the mercury vapor was expelled (see Figure 3).

The absorption cell was designed to give the greatest absorption at optimum conditions. The important parameters are: (1) focal distance of the reflecting mirror, (2) gas flow rate, (3) intensity of the source light, (4) detection limit needed, and (5) sample reaction time.

Barium perchlorate was chosen for the drying agent because of its high absorbing power for water.

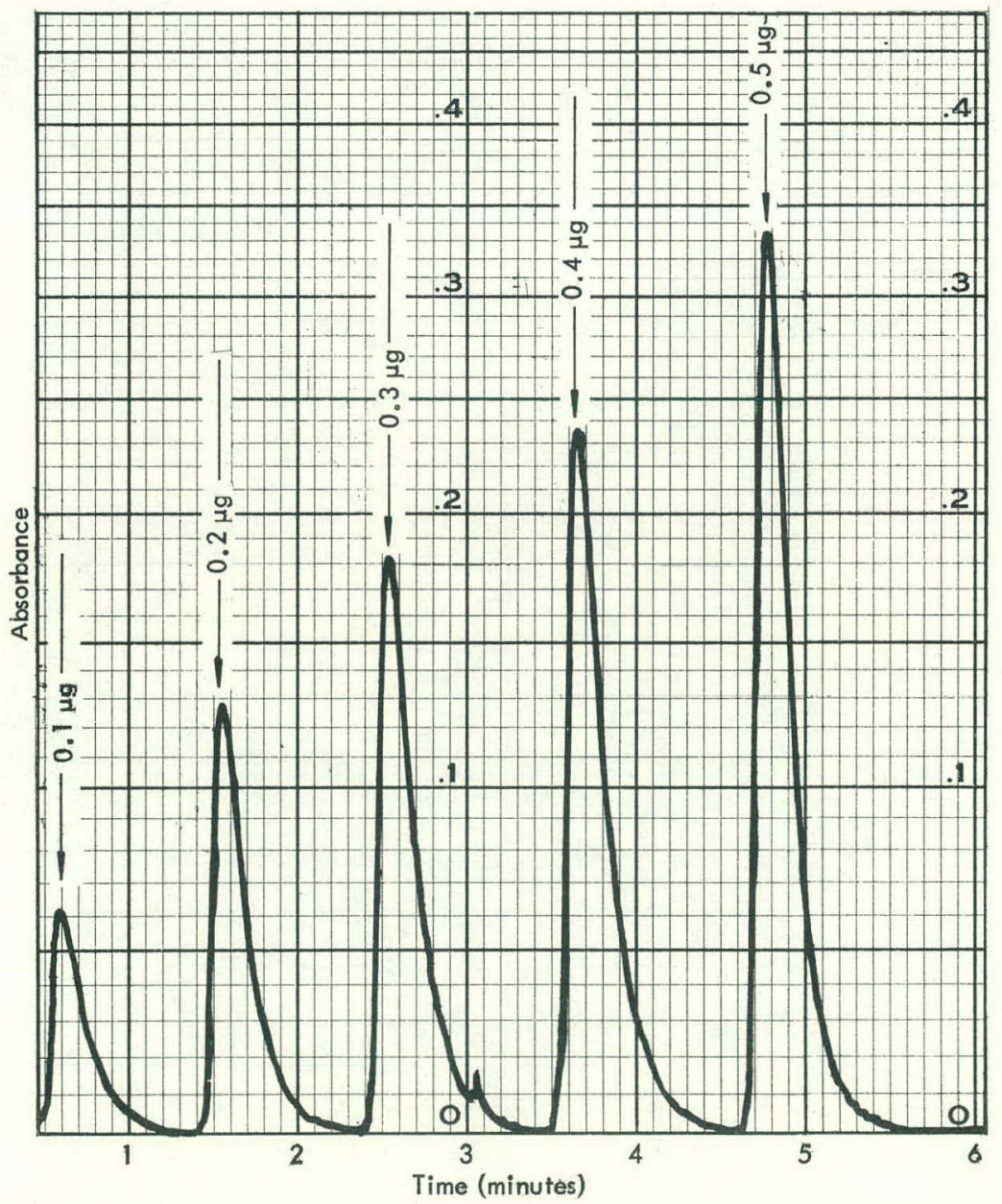

Figure 3. ABSORBANCE PEAKS FOR VARIOUS MERCURY STANDARDS SOLUTIONS. 


\section{REFERENCES}

(1) Dietrich, W.C.; Determination of Submicrogram Quantities of Mercury in Lithium Metal, Its Hydride, or Hydroxide, Y-1482; Union Carbide CorporationNuclear Division, Y-12 Plant, Oak Ridge, Tennessee (1965).

(2) Perkin-Elmer Corporation; Analytical Methods for Atomic Absorption Spectrophotometry; Norwalk, Connecticut (1966).

(3) Poleuktov, N.S., Vitkun, R. A., and Zelyukova, Yu. V.; "Determination of Milligamma Amounts of Mercury by Atomic Absorption in the Gas Phase", Zhurnal Analiticheskoi Khimii, 19, (8), pp 937-942 (1964).

(4) Ibid; p 941 